\title{
Arglabin as a potential drug in the treatment of Freund's complete adjuvant-induced arthritis in rats
}

\author{
Xiangchun Liu ${ }^{1 *}$, Heng $\mathrm{Jia}^{2}$, Hongsheng $\mathrm{Xia}^{3}$ \\ ${ }^{1}$ Department of Orthopedics, Dongzhimen Hospital, Beijing University of Chinese Medicine, Beijing, $100035,{ }^{2}$ Department of \\ Joint Surgery, Chinese Medicine Hospital of the Xinjiang Uygur Autonomous Region, Urumqi, 830000, ${ }^{3}$ Department of \\ Orthopedics, Huguosi Hospital, Beijing University of Chinese Medicine, Beijing 100035, China
}

*For correspondence: Email: xiangchunliu43@hotmail.com; Tel: 0086-10-84013276

Sent for review: 4 February 2018

Revised accepted: 27 July 2018

\begin{abstract}
Purpose: To investigate the anti-arthritic activity of arglabin in Freund's complete adjuvant- induced arthritis in rats, and the likely underlying mechanism.

Methods: A total of 40 male albino Wistar rats weighing between 120 and $150 \mathrm{~g}$ were used for this study. The rats were divided into four groups of ten rats each: control group, arthritis group, arglabintreated group, and standard (STD) group. Chronic arthritis was induced by injecting Freund's complete adjuvant in the plantar region of the rats. Rats in the arglabin-treated group received $5 \mathrm{ng} / \mathrm{g}$ arglabin intraperitoneally (i.p.), while those in the STD group received $1.5 \mathrm{mg} / \mathrm{kg}$ indomethacin, p.o. for 4 weeks. The development of arthritis was assessed at 0, 7, 14, 21 and 28th day of protocol by measuring thermal hyperalgesia, mechanical nociceptive threshold, arthritic score and paw volume. Activities of liver alkaline phosphatase $(A L P)$, alanine amino-transaminase $(A L T)$ and aspartate amino-transaminase (AST), and the levels of inflammatory cytokines -tumor necrosis factor- $\alpha$ (TNF- $\alpha$ ), interferon gamma (IFN- $y$ ), interleukin (IL) -6 and interleukin (IL)-1 $\beta$ were measured in the synovial fluid, while those of inflammatory mediators - thromboxane $B_{2}\left(T X B_{2}\right)$, prostaglandin $E_{2}\left(P G E_{2}\right)$ and leukotriene $B_{4}\left(L T B_{4}\right)$ were determined in serum. The expressions of mRNAs of nuclear factor kappa-light-chain-enhancer of activated $B$ cells $\left(N F_{k} B\right)$, cyclooxygenase-2 (COX-2) and inducible nitric oxide synthase (iNOS) were also determined in rat synovial tissues.

Results: Arglabin significantly decreased the paw swelling and arthritic scores, but significantly increased the paw withdrawal latency, when compared to the arthritis group $(p<0.05)$. It also attenuated the altered levels of inflammatory cytokines in arthritic rats, and significantly reduced the levels of inflammatory mediators, when compared to the arthritis group $(p<0.05)$. The expressions of $m R N A s$ of $N F_{k} B, C O X-2$ and iNOS also significantly decreased in arglabin-treated group, relative to the arthritis group $(p<0.05)$.

Conclusion: The anti-arthritic activity of arglabin is due to its effect on inflammatory pathway via decreases in the levels of inflammatory mediators and cytokines, and decrease in the expressions of $N F_{k} B, C O X-2$ and iNOS in the synovial tissues of arthritic rats.
\end{abstract}

Keywords: Arglabin, Arthritis, Freund's complete adjuvant, Inflammatory cytokines

This is an Open Access article that uses a funding model which does not charge readers or their institutions for access and distributed under the terms of the Creative Commons Attribution License (http://creativecommons.org/licenses/by/4.0) and the Budapest Open Access Initiative (http://www.budapestopenaccessinitiative.org/read), which permit unrestricted use, distribution, and reproduction in any medium, provided the original work is properly credited.

Tropical Journal of Pharmaceutical Research is indexed by Science Citation Index (SciSearch), Scopus, International Pharmaceutical Abstract, Chemical Abstracts, Embase, Index Copernicus, EBSCO, African Index Medicus, JournalSeek, Journal Citation Reports/Science Edition, Directory of Open Access Journals (DOAJ), African Journal Online, Bioline International, Open-J-Gate and Pharmacy Abstracts 


\section{INTRODUCTION}

Arthritis is an inflammatory disorder of the joints which affects approximately $10 \%$ of the world's population [1]. Osteoarthritis (OA) and rheumatoid arthritis (RA) are the two major types of arthritis. The latter is an autoimmune disorder associated with chronic inflammation that results in the loss of body movement [2]. There are about 10 million people afflicted with RA in China [3]. The disease leads to destruction of joints, damage to cartilage and bones, thus affecting the quality of life of sufferers [4]. Arthritis mainly affects the large joints, and causes swelling and pain due to alteration in the morphology of the joints. Osteoarthritis affects approximately $3.6 \%$ of the world's population [5], and it is an inflammatory disorder of joints characterised by joint pain, cartilage damage and development of osteophytes. Studies have revealed that inflammatory cytokines play important role in the pathogenesis of RA and OA [6], which are conventionally managed with non- steroidal antiinflammatory drugs (NSAIDs) and analgesics. However, apart from proffering only symptomatic relief, frequent use of NSAIDs causes gastric ulcer. Recently, the use of alternative medicine has been shown to elicit some beneficial effects in the management of arthritis. Arglabin, a sesquiterpene gamma-lactone isolated from different plant species such as Artemisia glabella, has tremendous pharmacological potential $[7,8]$. It possesses antimicrobial, antiinflammatory, neuroprotective and anticancer activities [9-11]. The anti-inflammatory property of arglabin is due to its capacity to alter the level of inflammatory cytokines, which confers on it a potential for the management of lung, ovarian, colon and breast cancers [12]. The aim of this study was to investigate the anti-arthritic activity of arglabin in Freund's complete adjuvantinduced arthritis in rats, and to identify the likely mechanism involved.

\section{EXPERIMENTAL}

\section{Animals}

Male albino Wistar rats $(120-150$ g) were procured from Jing Mei Company, China, and were housed under standard condition based on the guidelines of Association for the Assessment and Accreditation of Laboratory Animal Care International (AAALAC) for experimentation and animal use [13].The rats were acclimatized to laboratory conditions for a period of seven days, during which they had free access to normal standard chow and tap water. The protocol for this study was approved by the Institutional Animal Ethical Committee of Dongzhimen
Hospital, Beijing University of Chinese Medicine, China (DHBUCM/IAEC/02-2017).

\section{Induction of arthritis}

The rats were divided into four groups of ten rats each: control group, arthritis group, arglabintreated group and standard (STD) group. Rats in the arglabin-treated group received $5 \mathrm{ng} / \mathrm{g}$ arglabin, i.p., while those in the STD group received $1.5 \mathrm{mg} / \mathrm{kg}$ indomethacin, p.o., for a period of four weeks. Inactivated Mycobacterium tuberculosis $(10 \mathrm{mg}$ ) was dried in $1 \mathrm{ml}$ of paraffin oil for the preparation of complete adjuvant. Freund's complete adjuvant $(0.1 \mathrm{ml})$ was injected on the first day of protocol in the sub-plantar region of the rats, and on the $29^{\text {th }}$ day of protocol, blood was collected from the retro-orbital plexus of the rats under mild anesthesia and centrifuged at $3000 \mathrm{rpm}$ for $10 \mathrm{~min}$ to obtain serum which was used for biochemical analysis. The rats were sacrificed by cervical dislocation and their ankle joints were isolated for biochemical, histological and gene expression studies.

\section{Assessment of the development of arthritis}

Development of arthritis was assessed in the rats by measuring thermal hyperalgesia, mechanical nociceptive threshold, arthritic score and paw volume on $0,7,14,21$ and 28 days of protocol. The severity of arthritis was estimated on the five-point scale: score 0 was considered as no swelling, 1 for limited erythema and edema; 2 for erythema from the tarsal bone to ankle with slight edema, 3 for erythema from the tarsal bone to ankle associated with moderate edema, and 4 for erythema of entire leg associated with edema.

\section{Determination of the activities of liver enzymes in serum}

The activities of alkaline phosphatase (ALP), alanine amino-transaminase (ALT) and amino transaminase (AST) were estimated in the sera using their respective kits.

\section{Determination of the levels of inflammatory cytokines and mediators}

Enzyme-linked immunosorbent assay (ELISA) was used for the determination of concentrations of TNF- $\alpha$, IFN- $\gamma$, IL- 6 andIL- $1 \beta$ in synovial fluid, and serum levels of $\mathrm{TXB}_{2}, \mathrm{PGE}_{2}$ and $\mathrm{LTB}_{4}$.

\section{Reverse transcription-polymerase chain reaction (RT-PCR)}

Total RNA extraction reagent (RNAiso Plus) was used for the extraction of total RNA from the 
synovial tissues, while cDNA synthesis kit was used to perform the cDNA synthesis reaction according to the instructions of the manufacturer. Light Cycler 1536 Real-time PCR Detection System was used for the estimation of the expressions of mRNAs of $\mathrm{NF}_{\mathrm{k}} \mathrm{B}-\mathrm{p} 65, \mathrm{COX}-2$ and iNOS by quantitative RT-PCR. Variation in the cDNA content was normalized using glyceraldehyde-3-phosphate dehydrogenase (GAPDH). The PCR medium $(20 \mu \mathrm{l})$ which consisted of $6.4 \mu \mathrm{l}$ of $\mathrm{dH}_{2} \mathrm{O}, 1.6 \mu \mathrm{l}$ of genespecific primer $(10 \mu \mathrm{M}), 2 \mu \mathrm{l}$ of synthesized cDNA and $10 \mu \mathrm{l}$ of SYBR Premix Ex Taq ${ }^{\mathrm{TM}} \mathrm{II}$, was used to carry out the PCR reaction. Data was expressed as the mRNA expression of gene of the arthritic group relative to that of the normal or treated group.

\section{Statistical analysis}

Data are expressed as mean \pm SEM, and analyzed using Graph pad prism (6.1), while post-hoc comparison of the means was carried out using Dunnett's post-hoc test. The level of statistical significance was set at $p<0.05$.

\section{RESULTS}

\section{Effect of arglabin on paw swelling, arthritic score and paw withdrawal latency}

Effect of arglabin on paw swelling, arthritic score and percentage of paw withdrawal latency in arthritic rats was shown in Figure 1. There were significant increases $(p<0.01)$ in the paw swelling and arthritic score, and significant decrease in the paw withdrawal latency in the arthritis group, compared to the control group. However, in the arglabin-treated group, there were significant decreases $(p<0.01)$ in the paw swelling and arthritic score, and significant increase in the paw withdrawal latency in RA rat model, relative to the arthritis group $(p<0.01)$.

\section{Effect of arglabin on the activity of liver enzyme}

Effect of arglabin on the activities of liver enzymes in the sera of arthritic rats was shown in Figure 2. There were significant increases $(p<$ 0.05 ) in the activities ALT, AST and ALP in the arthritis group, when compared to control group. However, the arglabin and indomethacinetreated groups had significant reductions $(p<$ 0.05 ) in the activities of these enzymes, when compared to arthritis group.
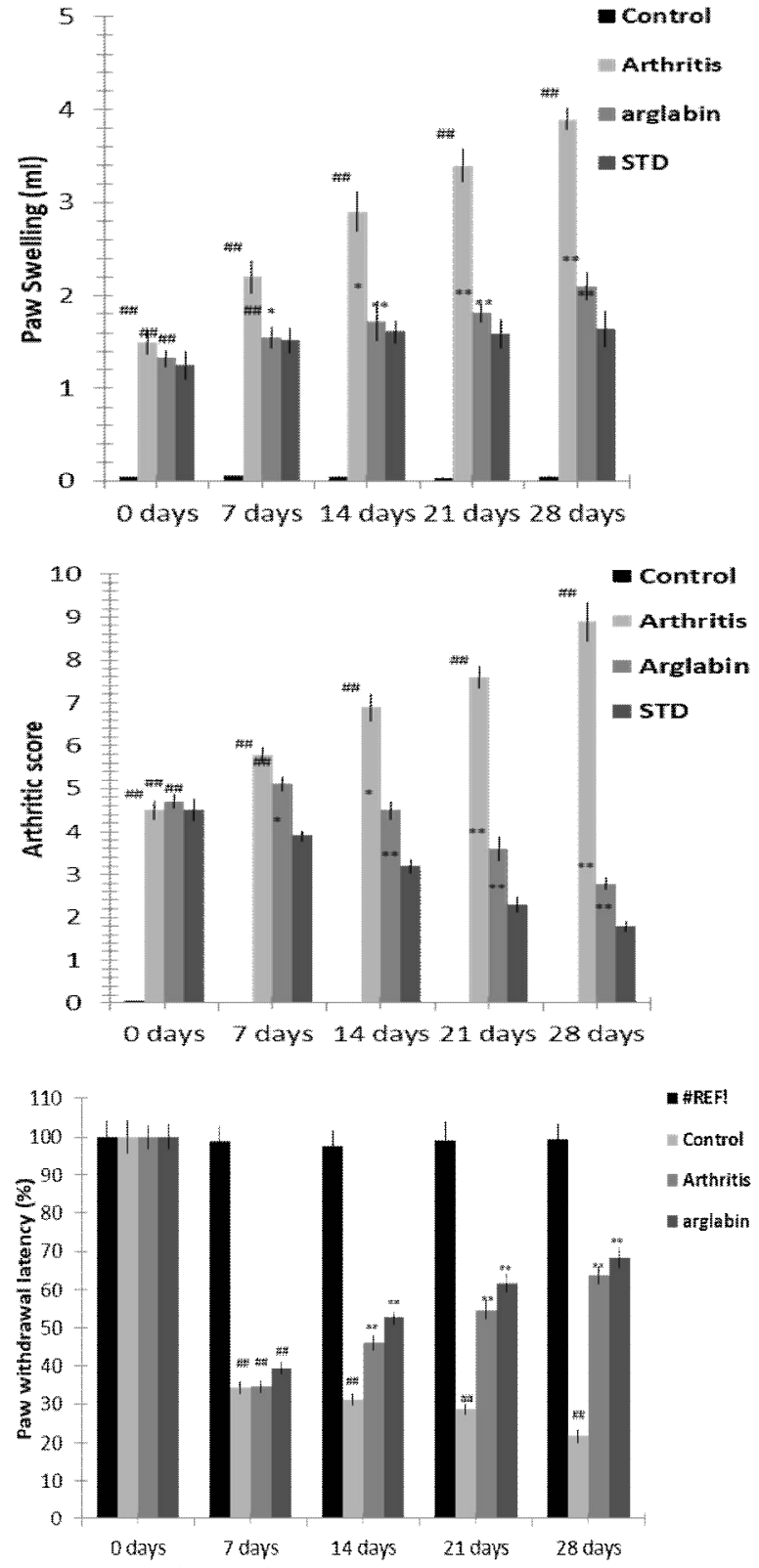

Figure 1: Effect of arglabin on paw swelling, arthritic score and paw withdrawal latency in arthritic rats. Mean \pm SEM $(n=6) ;{ }^{* \#} p<0.01$, compared to control; ${ }^{* *} p$ $<0.01$, compared to arthritis group

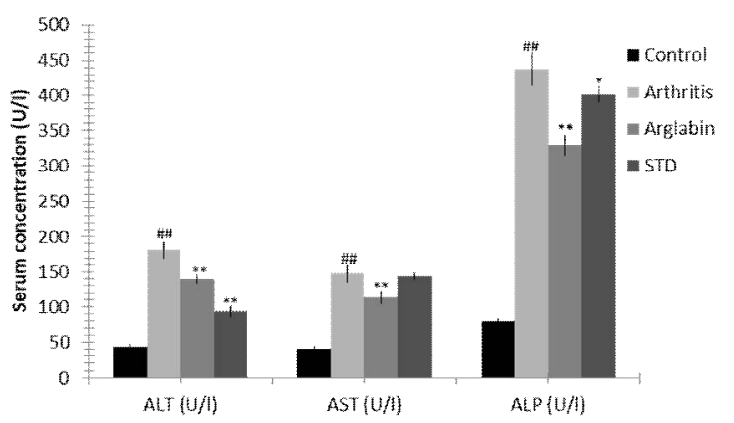

Figure 2: Effect of arglabin on the activities of liver enzymes in the sera of arthritic rats. Mean \pm SEM $(n=$

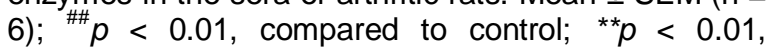
compared to arthritis group 
Effect of arglabin on the levels of circulating inflammatory cytokines

The effect of arglabin on the concentrations of inflammatory cytokines in the synovial fluid of arthritic rats are shown in Table 1. The levels of inflammatory cytokines (IL-1 $\beta$, IL-6, TNF- $\alpha$, and INF-y) were significantly enhanced up to 4 to 5 folds in the arthritis group, compared to control group $(p<0.05)$.

Table 1: Effect of arglabin on inflammatory cytokines in the synovial fluid of arthritic rats

\begin{tabular}{|c|c|c|c|c|}
\hline Group & $\begin{array}{l}\mathrm{IL-1} \beta \\
(\mathrm{ng} / \mathrm{l})\end{array}$ & $\begin{array}{l}\text { IL-6 } \\
\text { (ng/l) }\end{array}$ & $\begin{array}{l}\text { TNF- } \alpha \\
\text { (ng/l) }\end{array}$ & $\begin{array}{l}\text { INF-y } \\
\text { (ng/l) }\end{array}$ \\
\hline Control & $\begin{array}{l}43.72 \pm \\
3.16\end{array}$ & $\begin{array}{l}41.48 \pm \\
2.17\end{array}$ & $\begin{array}{l}79.23 \pm \\
3.61\end{array}$ & $\begin{array}{l}3.16 \pm \\
0.21\end{array}$ \\
\hline$A$ & $\begin{array}{l}181.40 \pm \\
11.83^{\# \#}\end{array}$ & $\begin{array}{l}147.33 \pm \\
12.29^{\# \#}\end{array}$ & $\begin{array}{l}437.30 \pm \\
23.10^{\# \#}\end{array}$ & $\begin{array}{l}7.59 \pm \\
0.37^{\# \#}\end{array}$ \\
\hline Arglabin & $\begin{array}{l}98.60 \pm \\
6.26^{\star \star}\end{array}$ & $\begin{array}{l}93.27 \pm \\
9.12^{* \star}\end{array}$ & $\begin{array}{l}219.10 \pm \\
14.70^{\star \star}\end{array}$ & $\begin{array}{l}6.28 \pm \\
0.27^{\star *}\end{array}$ \\
\hline STD & $\begin{array}{l}93.71 \pm \\
7.29^{\star \star}\end{array}$ & $\begin{array}{l}89.38 \pm \\
4.91^{* *}\end{array}$ & $\begin{array}{l}186.40 \pm \\
11.30^{\star \star}\end{array}$ & $\begin{array}{l}4.49 \pm \\
0.23^{\star *}\end{array}$ \\
\hline
\end{tabular}

Mean \pm SEM $(\mathrm{n}=6) ;{ }^{\#} p<0.01$, compared to control; ${ }^{\star *} p<0.01$, compared to the arthritis group

\section{Effect of arglabin on levels of inflammatory} mediators in the sera of arthritic rats

Effect of arglabin on the levels of inflammatory mediators in the sera of arthritic rats was shown in Table 2. The concentrations of inflammatory mediators $\left(\mathrm{TXB}_{2}, \quad \mathrm{PGE}_{2}\right.$, and $\left.\mathrm{TLB}_{4}\right)$ were significantly enhanced in the arthritis group, relative to the control group $(p<0.05)$. However, treatment with arglabin and indomethacin significantly reduced the levels of these inflammatory mediators in arthritic rats $(p<0.01)$.

Table 2: Effect of arglabin on levels of inflammatory mediators

\begin{tabular}{lccc}
\hline Group & $\mathrm{TXB}_{2}(\mathbf{n g} / \mathbf{l})$ & $\mathrm{PGE}_{2}(\boldsymbol{\mu g} / \mathbf{l})$ & $\begin{array}{c}\mathbf{L T B}_{4} \\
(\mathbf{n g} / \mathbf{l})\end{array}$ \\
\hline Control & $39.81 \pm$ & $1.09 \pm 0.08$ & $10.28 \pm$ \\
& 3.14 & $4.18 \pm$ & 1.01 \\
Arthritis & $79.26 \pm$ & $0.39^{\# \#}$ & $1.35^{\# \#}$ \\
& $5.38^{\# \#}$ & $1.23 \pm$ & $12.69 \pm$ \\
Arglabin & $42.71 \pm$ & $0.31^{\star \star}$ & $1.13^{\star \star}$ \\
& $2.93^{\star *}$ & $1.85 \pm$ & $15.27 \pm$ \\
STD & $34.29 \pm$ & $0.23^{\star \star}$ & $1.28^{\star *}$ \\
\hline
\end{tabular}

Mean \pm SEM $(\mathrm{n}=6) ;{ }^{\# \#} p<0.01$, compared to control; ${ }^{\star *} p<0.01$, compared to arthritis group

\section{Effect of arglabin on the expression of mRNAs of $\mathrm{NF}_{\mathrm{k}} \mathrm{B}, \mathrm{COX} 2$ and iNOS}

Effect of arglabin on the expression of mRNAs of $\mathrm{NF}_{\mathrm{k}} \mathrm{B}, \mathrm{COX} 2$ and iNOS was shown in Figure 3. The expressions of mRNAs of $\mathrm{NF}_{\mathrm{k}} \mathrm{B}, \mathrm{COX} 2$ and iNOS were significantly enhanced $(p<0.05)$ in the synovial tissues of arthritis group, compared to control, whereas they were significantly reduced $(p<0.05)$ in arglabin and indomethacintreated groups, when compared to the arthritis group.

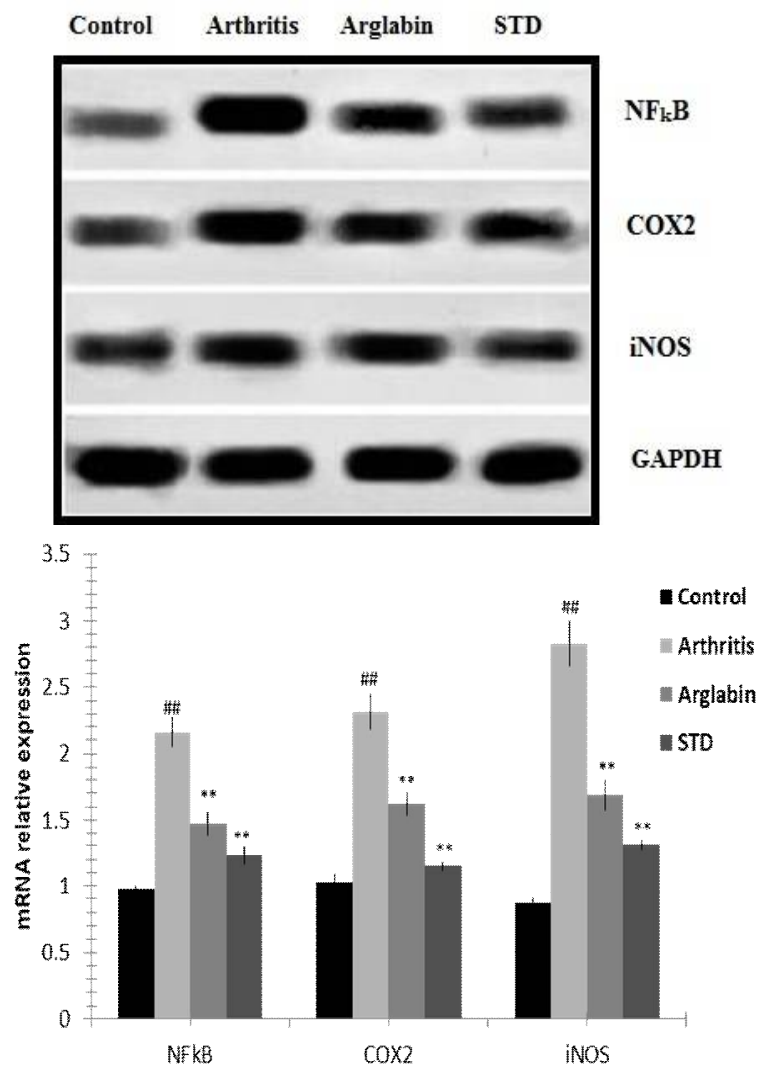

Figure 3: Effect of arglabin on the expressions of mRNAs of $N F_{k} B, C O X-2$ and iNOS in the synovial tissues of arthritic rats. Mean $\pm \operatorname{SEM}(\mathrm{n}=6) ;{ }^{\# \#} p<0.01$, compared to control; ${ }^{* *} p<0.01$, compared to arthritis group

\section{DISCUSSION}

The present study investigated the anti-arthritic activity of arglabin and attempted to postulate its possible mechanism of action. Arthritis was induced in the rats by a single injection of Freund's complete adjuvant and they were treated with arglabin for a period of four weeks. The results showed that paw swelling and arthritic score were significantly reduced, while paw withdrawal latency was significantly enhanced in arglabin treated-group compared to the arthritis group. Arthritis is mainly characterized by swelling of the synovium due to the proliferation of synovial cells [14], and studies have shown that the serum activities of ALP, ALT and AST increase due to hepatic lesions [15]. In the present study, activities of these hepatic enzymes were significantly increased in the sera of arthritic rats, which is in agreement with reports of previous studies that reported suggested an activation of enzymes and 
inflammatory mediators in arthritis [16]. However, the arglabin and indomethacine-treated groups showed a significant reduction in the activities of these enzymes, when compared to the arthritis group.

In arthritis, the concentrations of inflammatory mediators like $\mathrm{LTB}_{4}, \mathrm{PGE}_{2}$ and $\mathrm{TXB}_{2}$ are enhanced by lipoxygenase (LOX) and cyclooxygenase (COX) pathways. These mediators together enhance the vasodilatation, vascular permeability and blood flow in arthritis [17]. However, in arthritis, they cause resorption of bone by stimulating the production of matrix metalloproteinases (MMPs) [18]. Proinflammatory cytokines like IL-1 $\beta$, IL-6, TNF- $\alpha$ and INF-y play important roles in the pathogenesis of arthritis [19]. This is so because they increase erosion of bone, degradation and destruction of articular cartilage, and inflammation. Anti-inflammatory drugs used in the management of arthritis attenuate the altered levels of these inflammatory mediators and cytokines. The results of the present study revealed that the concentrations of the measured inflammatory cytokines increased by 4 to 5 folds in arthritis group, when compared to control. However, treatment with arglabin significantly decreased the levels of inflammatory mediators, relative to the arthritis group.

Parameters of inflammatory cascade such as $\mathrm{NF}_{\mathrm{k}} \mathrm{B}, \mathrm{COX}-2$ and iNOS play substantial roles in the pathogenesis of arthritis. The expressions of adhesion molecules and inflammation mediators depend on the activation of $\mathrm{NF}_{\mathrm{k}} \mathrm{B}$, while COX-2 catalyzes the synthesis of $\mathrm{PGE}_{2}$ whose concentration increases in arthritis [20]. However, activation of iNOS enhances the synthesis of nitric oxide (NO) which causes tissue damage and inflammation of joints [21]. In the present study, the expressions of mRNAs of $\mathrm{NF}_{k} \mathrm{~B}, \mathrm{COX}-2$ and iNOS were significantly enhanced in the synovial tissues of rats in the arthritis group, whereas they were significantly reduced in arglabin and indomethacin-treated groups, when compared to the arthritis group. However, treatment with arglabin attenuated the altered expressions of $\mathrm{NF}_{\mathrm{k}} \mathrm{B}, \mathrm{COX}-2$ and $\mathrm{NOS}$ in the synovial tissues of the arthritic rats.

\section{CONCLUSION}

These results indicate that the anti-arthritic activity of arglabin is due to its potential effect on inflammatory pathway through decrease in the levels of inflammatory mediators and cytokines, and reduction in the expressions of $\mathrm{NF}_{k} \mathrm{~B}, \mathrm{COX}-2$ and iNOS in the synovial tissues of arthritic rats.

\section{DECLARATIONS}

\section{Acknowledgement}

Special thanks to Dongzhimen Hospital, Beijing University of Chinese Medicine, China, for providing facilities and support for this work.

\section{Conflict of Interest}

No conflict of interest associated with this work.

\section{Contribution of Authors}

The authors declare that this work was done by the authors named in this article and all liabilities pertaining to claims relating to the content of this article will be borne by them.

\section{REFERENCES}

1. Atzinger CB, Guo JJ. Biologic disease-modifying antirheumatic drugs in a national, privately insured population: utilization, expenditures, and price trends. Am Health Drug Benefits. 2017; 10: 27-36.

2. Chimenti MS, Triggianese $P$, Conigliaro $P$, Candi $E$, Melino G, Perricone $R$. The interplay between inflammation and metabolism in rheumatoid arthritis. Cell Death Dis. 2015; 6: 1887.

3. Jin S, Li M, Fang Y, Li Q, Liu J, Duan X, Liu Y, Wu R, Shi $X$, Wang $Y$, et al. Chinese Registry of rheumatoid arthritis (CREDIT): II. Prevalence and risk factors of major comorbidities in Chinese patients with rheumatoid arthritis. Arthritis Res Ther. 2017; 19: 251.

4. Lim MA, Louie B, Ford D, Heath K, Cha P, Lacroix JB, Lum PY, Robertson TL, Schaevitz L. Development of the digital arthritis index, a novel metric to measure disease parameters in a rat model of rheumatoid arthritis. Front Pharmacol.2017; 8: 818.

5. Litwic $A$, Edwards $M$, Dennison $E$, Cooper $C$. Epidemiology and burden of osteoarthritis. Br Med Bul. 2013; 105: 185-199.

6. Sokolove J, Lepus CM, Role of inflammation in the pathogenesis of osteoarthritis: latest findings and interpretations. Ther Adv Musculoskelet Dis. 2013; 5 (2): 77-94.

7. Ivanescu B, Miron A, Corciova A. Sesquiterpene lactones from artemisia Genus: biological activities and methods of analysis. $J$ Analytical Methods Chem. 2015;2015:247685.

8. Schepetkin IA, Kirpotina LN, Mitchell PT, Kishkentaeva AS, Shaimerdenova ZR, Atazhanova GA, Adekenov SM, Quinn MT. The natural sesquiterpene lactones arglabin, grosheimin, agracin, parthenolide, and estafiatin inhibit $T$ cell receptor (TCR) activation. Phytochem. 2018; 146: 36-46.

9. Anke H, Sterner O. Comparison of the antimicrobial and cytotoxic activities of twenty unsaturated

Trop J Pharm Res, August 2018; 17(8):1589 
sesquiterpenedialdehydes from plants and mushrooms. Planta Med. 1991; 57: 344-346.

10. Abderrazak AEl, Hadri K, Bosc E, Blondeau B, Slimane $M N$, Büchele $B$, Simmet $T$, Couchie $D$, Rouis $M$. Inhibition of the inflammasome NLRP3 by arglabin attenuates inflammation, protects pancreatic $\beta$-cells from apoptosis, and prevents type 2 diabetes mellitus development in ApoE2Ki mice on a chronic high-fat diet. J Pharmacol Experimental Therapeu.2016; 357: 487494.

11. Kalyieva S, Minakova N, Yukhnevich-Nassonova Y. Costeffectiveness analysis of the original drug arglabin. Value in Health. 2014; 17; A734-735.

12. Lone SH, Bha KA. Hemi-synthesis of a naturally occurring clinically significant antitumor arglabin from ludartin. Tetrahedron Letters. 2015; 56: 1908-1910.

13. Naik SR, Wala SM. Arthritis, a complex connective and synovial joint destructive autoimmune disease: Animal models of arthritis with varied etio-pathology and their significance. Narrative Rev. 2014; 60: 309-317.

14. Balagué C, Pont M, Prats N, Godessart N. Profiling of dihydroorotate dehydrogenase, p38 and JAK inhibitors in the rat adjuvant-induced arthritis model: a translational study. British J Pharmacol. 2012; 166; 1320-1332.

15. Liukkonen MK, Mononen ME, Klets O, Arokoski JP, Saarakkala S, Korhonen RK. Simulation of subjectspecific progression of knee osteoarthritis and comparison to experimental follow-up data: data from the osteoarthritis initiative. Sci Rep. 2017; 7: 9177.

16. Shoeb M, Ramana KV. Anti-Inflammatory effects of benfotiamine are mediated through the regulation of arachidonic acid pathway in macrophages. Free Radic Biol Med. 2012; 52: 182-190.

17. Nanjundaiah SM, Astry B, Moudgil KD. Mediators of inflammation-induced bone damage in arthritis and their control by herbal products. Evid Based Complement Alternat Med. 2013; 2013: 518094.

18. Strober W, Fuss IJ. Pro-inflammatory cytokines in the pathogenesis of IBD. Gastroenterol. 2011; 140: 17561767.

19. Calder PC. Omega-3 fatty acids and inflammatory processes. Nutrients 2010; 2: 355-374.

20. Rainbow R, Ren W, Zeng L. Inflammation and joint tissue interactions in $O A$ : implications for potential therapeutic approaches. Arthritis. 2012; 2012: 741582. 